\title{
Modernization Education System of Dayah Terpadu Al-Azhar
}

\author{
Ismet Nur* \\ Doctoral Student, Postgraduate Program, State Islamic University of North Sumatra, Medan, Indonesia \\ ismet_nur@yahoo.com \\ ${ }^{*}$ Corresponding Author
}

How to Cite : Nur, I. (2019). Modernization Education System of Dayah Terpadu Al-Azhar. International Journal for Educational and Vocational Studies, 1 (8), 848-853. DOI: https://doi.org/10.29103/ijevs.v1i8.2237

\section{ARTICLE HISTORY}

Received: 19 September 2019

Revised: 28 October 2019

Accepted: 10 November 2019

\section{KEYWORDS}

Modernization;

Education System;

Dayah Terpadu Al-Azhar;

\section{ABSTRACT}

The existence of dayahs in Central Aceh is an Islamic educational institution that contributes in influencing the religious life of the community, day by step the development of both the quantity and quality is increasing. This study aims to describe the modernization Education System of Dayah Terpadu Al-Azhar, includes sub-systems of dayah education. This research is a field research with a descriptive qualitative method using a phenomenological approach, the main data source of this study is the document, and the informants are leaders of dayah, teungku dayah, santri and community leaders. Modernization education system of Dayah Terpadu Al-Azhar is characterized by changes in objectives, teungku and santri dayah, implementation of an integrated curriculum, enriching the treasures of contemporary books, the use of active strategies and varied methods, development of the dayah environment, and evaluation of learning.

This is an open access article under the CC-BY-SA license.

\section{INTRODUCTION}

Dayah is one of the Islamic educational institutions in Aceh Tengah as a result of transformation from zawiyah. Zawiyah at the beginning of its use refers to the corner of a building, mosque, where a group of people gather to hear the teachings of a shaykh Zawiyyat (Asari, 2017). High level education (Mukti, 2017). The organization of dayah education is proven to be able to produce strong cadres of ulama and fighters in Aceh and contribute to fostering the religious life of the community. Hasbi Amiruddin stated that dayah never stopped printing cadres of Islamic fighters. The development of dayahs from the coast of Samudra Pasai (Aceh Utara Now) and Perlak (now known as Aceh Timur) spread throughout Aceh and the interior of Gayo, Islamization to Gayo began in the 16th century through scholars who graduated from dayah-dayah in Aceh such as Dayah Cot Kala. Adi Geunali is a person who is very instrumental in bringing Islam to the Islamic kingdom of Lingga (Aceh Tengah) (Yacob, 2010).

Dayah played a role in the process of Islamization in Aceh Tengah, through a network of dayah alumni who spread and established the Islamic kingdoms of the Lingga kingdom (Aceh Tengah) (Yacob, 2010). Hasjimy noted that the Seureuleu dayah in Aceh Tengah stood between 1012-1059M (Amiruddin, 2013) with its main role of spreading Islam in the Islamic kingdom of Lingga (Aceh Tengah), printing its santri tafaqqatu fiddin and living and practicing sincerely solely intended for the service of Allah swt in life and lives (Maksum, 2003).

The development of dayahs in Aceh Tengah evolved according to the demands of community development needs, aimed at giving birth to Ulama as preachers, during the colonial era the dayah not only gave birth to Ulama but also played a role in giving birth to mujahids and aroused the spirit of expelling invaders. Post independence, the orientation of the identical dayah with the aim of Islamic education includes; preservation of values, according to social needs, preparing students as competent workforce in their respective fields, oriented towards the future development of science and technology.

In the empire, dayah offered three levels of teaching, namely; rangkang (junior), bale (senior), and dayah manyang (university). Dayah is also one place to study and develop knowledge and culture (Silahuddin, 2016). The development of dayah education in Aceh is increasingly strong, the community places the hope of religious education on dayah as a bastion of religious education to instill Islamic values, give birth to scholars, preachers, educators, leaders, so as to be able to solve various problems of the people, modernization of dayah 
education touches change and progress of the education system. To develop the quality of dayah education there is a need for development in each sub-system of education which includes, objectives, teungku dayah, santri, manhaj (curriculum), learning strategies and methods, environment, and evaluation as an effort to adapt to the needs of the times, modernization of Islamic education cannot separated by the rise of the Muslims in modern times (Kirana, 2017).

In the Nanggroe Aceh Darussalam (NAD) Qanun No. 23/2002 and Aceh Qanun No. 11/2014 Dayah/Islamic boarding school is a community-based Islamic educational institution that organizes Diniyah education or integrated with other education where $u l l \bar{a} b$ or santri are boarded / boarded at the dayah/pesantren (balee/pondok). Article 39 (2) Dayah/Pesantren education units consist of: Salafiah Dayah, and Integrated/Modern Dayah. Integrated dayah applies an integrated education pattern by integrating a salafi (traditional) dayah education system with a (modern) khalafi system, organizing a khalafi system is a solution for dayah education in meeting the development needs of superior human resources according to the needs of the times.

According to data from Aceh Tengah Dayah Development Board in 2019, Aceh Tengah district has 27 dayahs, with a population of $99 \%$ Muslim, the community is very concerned about religious education through dayah education, therefore the dayahs in Central Aceh district can survive and develop. Dayah Terpadu Al-Azhar is an integrated dayah that had been established since 2010 and was awarded type A for the district of Aceh Tengah. The effort to develop Dayah Teroadu Al-Azhar is a response to the progress of the times and social change to the needs of community development, dayah has a high commitment in advancing Acehs' education (Marzuki, 2011).

This article is the result of field research using descriptive qualitative methods and using a phenomenological approach. The study was conducted at the Dayah Terpadu Al-Azhar, which discussed the modernization of the dayah education system which included objectives, teungku and dayah students, curriculum, learning strategies and methods, dayah environment, and evaluation of learning. Based on the description above, the writer is interested in studying more deeply about "Modernization Education System of Dayah Terpadu Al-Azhar".

\section{LITERARURE REVIEW}

\subsection{Education System of Dayah Terpadu Al-Azhar}

Dayah Terpadu Al-Azhar Paya Jeget is one of the Islamic educational institutions in Aceh Tengah district which was founded in 2010, by Tgk. Khairul Basari, MA, and domiciled in Kampung Paya Jeget, Pegasing Subdistrict, Aceh Tengah Regency. The Dayah Terpadu Al-Azhar is held in an integrated (khalafi/modern) manner which integrates traditional dayah (salafi) and modern dayah (khalafi) traditions. Historical travels noted that the dayah contributed to fostering the religious competence of the community in implementing Islamic sharia in Aceh Tengah. In accordance with Hasbi Amiruddin's statement. If the word "dayah" stopped operating a few decades before, there might not be any more desire to implement Islamic sharia in Aceh (Amiruddin, 2013).

Dayah education is very open to the needs of the times, as evidenced when dayah dares to appear as an institution in its era. The modernization of the dayah education system, began during the Dutch colonial era, when the Dutch Colonial Government introduced the school education system, to expand opportunities for pribumi, to enjoy modern education. According to Eko Setiawan Modernization means the latest, the latest, or the attitude and way of thinking in accordance with the demands of the times. Modernization education system of Dayah Terpadu Al-Azhar when viewed from the aspect of the education system there are changes in the sub-system of dayah education, the modernization of the dayah education system can also be interpreted as an integration of Islamic teachings with science and faith. The following will modernize the Dayah Terpadu Al-Azhar education system, including: Objectives, teungku, santri, curriculum, strategies and methods, environment, and evaluation of learning.

\subsection{Purpose of Dayah Education}

Mining of the times and social change requires a new paradigm from an educational institution so that its existence still exists as an educational institution capable of giving birth to a tough generation that has competencies and skills that are reliable, in 2010 it was an era of digitalization of the condition of the people in Aceh Tengah district. reforming and structuring the religious life of the people, the phenomenon of morality of the nation's children who display a variety of negative actions is almost limitless, the limitations of religious education institutions are a strong enough reason, to increase efforts to reform these.

Based on this context, Tgk, Khairul Basari, MA, made it an opportunity to establish an integrated dayah, with the aim of meeting the community's needs for the existence of educational institutions that are expected to be able to fix, organize and overcome the problems being faced, this was explained by Muslim Thahiry stating " the existence of dayah as an educational institution with its traditional education system is expected to be able to overcome the problems being faced including the creed and the destruction of Islamic values ". In addition, the establishment of Dayah Terpadu Al Azhar also aims to form students who have faith and are devoted to Allah, virtuous, knowledgeable, charitable and sincere, and serve the community, in order to give birth to Muslim scholars and scholars, by sticking to the Qur'an and the Sunnah Rasulullah SAW. 
Development on aspects of dayah education objectives in addition to being able to produce cadres of scholars, Muslim scholars, generations of believers and devoted to Allah, having good morality, wide-minded, obedient and obedient in carrying out Islamic sharia, and responsive to the changing times. Also expanding the goals, vision and mission of dayah education to realize the ideals of the Indonesian people in order to make the life of the nation worse, and reduce the number of dropouts based on the principle of education for all, producing graduates who are noble, independent, disciplined, skilled, responsible, broad-minded, and respect for development needs both regionally and nationally through the implementation of dayah education, able to fill a variety of jobs in filling the needs of development and social change armed with competencies and skills possessed.

\subsection{Teungku Dayah}

Teungku is an educator and ulama figure as a leader in dayah. This status is obtained because of the mastery of Islamic values and obedience in carrying out the teachings of Islam in everyday life, so that the figure of teungku became an exemplary figure respected by the community with the authority and charisma inherent in a teungku, in the tradition of the teungku or ulama functioned as educators and actors changing the dayah education, according to M. Hasbi Amiruddin explained "every dayah in which there is a teungku or ulama, clearly as a center of growth of Islamic knowledge" (Amiruddin, 2013).

Dayah Terpadu Al-Azhar was founded in 2010 by Tgk. Khairul Basari, MA, assisted by 5 teacher assistants. The term teungku is generally used by the people of Aceh to refer to scholars in the tradition of Muslim communities in the Aceh region. Teungku dayah has charisma that usually owns or nurtures the dayah, teaches classical books (yellow books) and has an attachment to traditional Islamic groups (Dhofier, 1985).

Teungku is a human resource of the dayah education system which is managed according to the needs of the dayah, Human Resources management, can be interpreted as the management of individuals who work in organizations in the form of relations between workers and workers, especially to create and utilize individuals productively as efforts to achieve organizational goals and in order to realize job satisfaction and fulfill the needs of these individuals (Dhofier, 1985).

Teungku dayahs with S2 academic qualifications: 1 person, S1: 3 people, and Madrasah Aliyah (MA) / Dayah: 1 person, this number certainly does not match the ratio of students in subject matter that demands a balanced availability of Teungku resources. In 2014 the number of teunkgu increased to 12 people, with details: S2: 1 person, S1: 7 people, Madrasah Aliyah (MA)/Dayah: 4 people, teungku dayah is a graduate of dayahs in Aceh.

In 2017 the quantity of teungku dayah experienced good development, the condition of teungku dayah numbered 25 people with details of S2: 3 people, S1: 15 people, and MA/SMA/Dayah: 7 people. The teungku dayah recruitment pattern does not go through a selective recruitment process, but the leadership conducts networking through colleagues, friends and the community. Teungku dayah is fully responsible for the development of competencies and skills of students for 24 hours.

\subsection{Dayah Students}

Santri are students who study at dayah, the state of santri at the beginning of the dayah was established in 2010 not widely known to the wider community, at that time the dayah was still in demand among certain people from Paya Jeget and surrounding villages. Since dayah opened secondary level registration (dayah education), community enthusiasm increased not only from the Paya Jeget village, but also from other villages, in the districts of Aceh Tengah, Bener Meriah, and Gayo Lues (Basari, 2019). Statistics on the development of students can be seen in the table below:

Table 1. Data on the development of Dayah Terpadu Al-Azhar Payajege Studentst

\begin{tabular}{cccccc}
\hline \multirow{2}{*}{ No. } & Year & \multicolumn{5}{c}{ Unit } & Amount & Info. \\
\cline { 3 - 6 } & & TPA & SLTP & SLTA & \\
\hline 1 & 2010 & 23 & - & - & 23 \\
\hline 2 & 2011 & 80 & - & - & 80 \\
\hline 3 & 2012 & 120 & - & - & 120 \\
\hline 4 & 2013 & 340 & - & - & 340 \\
\hline 5 & 2014 & 150 & 32 & - & 182 \\
\hline 6 & 2015 & 250 & 95 & - & 345 \\
\hline 7 & 2016 & 300 & 185 & - & 485 \\
\hline 8 & 2017 & 90 & 191 & 17 & 298 \\
\hline 9 & 2018 & - & 258 & 48 & 306 \\
\hline 10 & 2019 & - & 302 & 90 & 392 \\
\hline \multicolumn{7}{c}{ Total Number } & 1353 & 1063 & 155 & 2554 \\
\hline Sources: Dayah
\end{tabular}

Sources: Dayah financial statement documents for 2018, p. 13. Data obtained from Tgk. Bajaruddin, SE as treasurer of the Al-Azhar Payajeget dayah, on Monday 15 April 2019 at $10.28 \mathrm{PM}$.

The total number of santri in 2019 was 2554 with details of TPA student: 1353 people, student wușta (SMP) level: 1063 people, and student 'ulya (SMA) level: 155 people. The development of the quantity of dayah santri continued to experience ups and downs, the development of student was influenced by the socialization of the existence of dayahs, the availability of facilities and infrastructure, and services to studentguardians of santri.

\subsection{Dayah Education Curriculum}

The curriculum developed at Dayah Terpadu Al-Azhar is the Islamic religious sciences or related to Islamic religious sciences, according to the objectives of the institution to be achieved, the material in the dayah curriculum is prepared based on the needs of dayah in structuring public understanding of Islamic religious 
sciences, and adapted to the ability of teungku in mastering the books, this was also explained by Ismail Yacob, subject matter, systems and books studied were not arranged in a particular curriculum, but very much dependent on the ability of the leader of the dayah leaders and the wishes of the students themselves (Yacob, 2010).

The distribution of subject matter in Dayah Terpadu Al-Azhar was compiled by the founder/leader, taking into account the conditions of the community that were compiled in an integrated manner while maintaining the salafi (traditional) dayah curriculum and adopting the khalafi (modern) dayah curriculum, and making adjustments to the curriculum compiled by the education office dayah Aceh (Bajaruddin, 2019).

The development of the dayah curriculum has made fundamental changes to the implementation of the curriculum at the classroom level in the form of improved learning systems including management and supervision. Curriculum changes were made by expanding the scope of the curriculum compiled by the Aceh dayah education office and adding to the wealth of reference books both classic and contemporary as a development of learning resources. increasing the number of books is expected to be able to increase understanding and broaden students' perspectives in certain fields, material that gets a lot of references, namely interpretation, jurisprudence, nahwu sharaf, hadith, and morals. By enriching the collection of books proven able to also improve language skills, especially what 4 language skills (maharah al-lughah).

\section{METHODS}

Learning strategies and methods serve to make it easier to deliver material to students, the development of learning strategies and methods by implementing oriented strategies to activate students, and using a variety of methods, while maintaining classic strategies and methods and integrating them with active learning strategies, and methods variative (Basari, 2019), in order to create a learning atmosphere that is fun and membisakan.

The learning process uses traditional strategies and methods carried out from generation to generation by adopting active learning strategies, namely expository, participatory, inkuiri, problem solving (masāilul bahsii), and using various methods, namely: lectures, questions and answers (muwajahah), debates (munadzarah), discussions, assignments (wazifah), tahfiz, field trips (rihlah), practices (tamrinat), muhawarah, muhadasah, and muhāạarah. Learning is done by studying classic and contemporary books and books.

\subsection{Dayah Education Environment}

The dayah education environment is the area and all the devices within it, as an environmental education system sub-dayah forms a unified space with all objects, power, circumstances, and living things, including humans and their behavior, which affect the continuity of dayah education. The dayah education environment includes climate and geography, residence, customs, knowledge, education and nature. Thus the environment is everything that appears and exists in the realm of life that is always used for the development of dayah education.

Changes in the environment are identical to public facilities, in the form of locations and public buildings, such as the availability of sports facilities, libraries and canteens, parking locations, parks and access roads. From the side of the building has been seen to adopt like a modern style in the dayah environment as the school building we see today (Mashuri, 2013). The existence of a dayah must be supported by conducive environmental conditions with adequate facilities, steps to complete the dayah facility and the creation of a conducive climate is a stream of modernization that occurs in the dayah environment.

The physical development of the environment has changed since the dayah only had 1 bale unit, 1 class unit, 1 dormitory unit on a $25 \times 50$ meter land, today the dayah has been built on $12000 \mathrm{~m}^{2}$ land and is equipped with dormitory facilities, classrooms, offices, mosques, mushalla putri, teungku house, teungku dormitory, learning facilities, sports, bathrooms, canteens/ cooperatives, computer facilities, sewing machines, internet corners, access roads, lighting, clean water. And form a climate of dayah, has arranged the order (nidam) to regulate the behavior in the dayah about learning, worship, exercise, rest, cooking and eating.

The Dayah Terpadu Al-Azhar was established in 2010 on an area of $25 \times 50$ meters, with a private house building (Tgk. Khairul Basari, MA) used as a place of learning, a bale building (house on stilts) measuring $7 \times 8$ meters as a place to study and pray together in congregation, and 1 unit. In 2014 an area of 1 hectare was expanded, on which land a 1xx8 meter building was built for a male dormitory and a ground floor for a classroom, also building a $6 \times 8$ meter cage, a public kitchen, a canteen, and building 1 classroom (RKB) Permanent sourced from APBK and female dormitory 2 units, the first building is made of wood/boards, now the building is switched to concrete (permanent) on top of a total area of $12,000 \mathrm{~m} 2$ which is a location for dayah development, we continue to develop for development dayah (Basari, 2019).

The created cultural climate leads to the formation of Muslim character. Culturally, the preservation of scientific and religious traditions in the pesantren is very dependent on the value system it holds, such as the almost unlimited admiration of science, teachers or kyai (Basyit, 2017). Culture is a social phenomenon that is produced by a group of people in a certain time and place that naturally affects the group members' behavior (Silahuddin, 2015). The dayah environment greatly influences the formation of academic culture to support the achievement of dayah education goals.

The development of the Dayah Terpadu Al-Azhar environment, in the aspect of infrastructure, was carried 
out by the addition of santri dormitories, study rooms, offices, and IT equipment such as computers, etc. The hallmark of dayah education is a developing mosque, Dayah built a mosque as a means of worship and a center for planting and fostering Islamic religious values, laying the first stone of the Dayah Terpadu Al-Azhar mosque was carried out in 2016, as a forerunner to the building of mosques in the dayah environment, with the founding of the mosque, and building strong traditions with Islamic nuance make santri more accustomed to santri-style life in a religious environment, santri who are accustomed to life with religious nuances will shape and are believed to be able to change behavior, skills and attitudes in a good direction.

\section{RESULT AND DISCUSSIONS}

\subsection{Evaluation of Dayah Education}

In the learning process at the Dayah Terpadu Al-Azhar, the first standing was not using structured evaluation, to measure the ability of students, students were asked to read, translate, and explain the contents of the book, the ability to memorize, the use of evaluation has been changed using test and non-test evaluation techniques, non-test evaluation using observation, evaluation of the test using the semester exam, and at the end of the study period students are required to compile a miniscription, the acquisition of a value contained in a report card (kasyfud darajah), and as a sign of graduation students get a diploma (shahadah).

To measure the level of success of students in learning using evaluation techniques by testing the ability to master the book by students, mastery of the book includes: the ability to read, interpret, explain the contents of the book and the structure of the sentence (i'rāb). Changes to the evaluation used in Dayah Terpadu Al-Azhar besides conducting observations, and a test of mastery of the book, as well as delegating material, evaluations are carried out systematically and scheduled every semester by holding exams at the end of the semester, examinations are carried out on all dayah subject matter by doing written tests and oral tests, and the results of the exam are included in report cards dayah (kasyfud darajah) (Basari, 2019).

Learning evaluation of students 'abilities in the cognitive domain which includes: First the students' ability to memorize letters, hadiths, prayers, mufradat, nahwu and saraf material, the ability to remember (memorize) students is evaluated by memorizing, translating, translating and write it properly and correctly. Secondly, the students' ability in understanding books, subject matter, and memorization. Students' understanding of books and other subject matter is evaluated by asking students to explain and describe in detail the contents of the material contained in books and subject matter. Third, the ability of students to apply theories and their understanding of books, the ability of students to apply theories and their understanding is evaluated by testing the ability of students to demonstrate and actualize their understanding in daily life. Fourth, the ability of students to analyze to elaborate or elaborate on subject matter, this ability is evaluated by way of students thinking well about the real form of material that is understood by students in the classroom at the hostel, and in daily life, the ability to analyze students in the learning process is evaluated in the ability students debate. Fifth, the ability of students to integrate the parts of the subject matter logically, the ability of this synthesis is characterized by students can write insha" essay about the part of the subject matter that has been studied. Sixth The ability of students to make a consideration of a condition, students are able to weigh the benefits and harms or the impact that will arise from a problem faced. This ability is evaluated in learning by using problem solving strategies (bahsul masā'il) student work together to find solutions to each problem or theme given.

\section{CONCLUSION}

Modernization education system of Dayah Terpadu Azhar, marked by changes in the education sub-systems which include: the objectives of dayah education, increasing the quantity, competency and academic qualifications of teungku academic dayah, the development of the number and patterns of student recruitment, integrating the traditional dayah curriculum and modern dayah, the application of active strategies and varied learning methods, the expansion of the dayah area and the complementary facilities and facilities of effective supporting infrastructure, the application of culture through more systematic rules, and the use of effective learning evaluations to measure learning outcomes in the cognitive, affective and psychomotor domains, conduct daily, weekly, semester, monthly and yearly exams.

\section{REFERENCES}

Amiruddin, M. Hasbi. (2013). Menatap Masa depan Dayah di Aceh, Banda Aceh: PeNA.

Anwar, M. (2013). Modernisasi Pesantren: Pergeseran Tradisi dan Pudarnya Kyai. Hunafa: Jurnal Studia Islamika, 10(1).

Asari, Hasan. (2017). Menyingkap Zaman Keemasan Islam, Bandung: Citapustaka Media Perintis.

Basyit, A. (2017). Pembaharuan Model Pesantren: Respon Terhadap Modernitas. Kordina-Jurnal Komunikasi Antar Perguruan Tinggi Agama Islam, 16(2), 293-324.

Dhofier, Zamakhsyari. (1985). Tradisi Pesantren: Studi Tentang Pandangan Hidup Kiai, Jakarta: LP3ES.

Kirana, Z. C. (2017). Pandangan Azyumardi Azra terhadap Modernisasi Pesantren. INOVATIF: Jurnal Penelitian Pendidikan, Agama dan Kebudayaan, 3(1), 77-94. 
Maksum. (2003). Pola Pengembangan Pondok Pesantren. Jakarta: Direktorat Jenderal Kelembagaan Agama Islam.

Marhamah, M. (2018). Pendidikan Dayah dan Perkembangannya Di Aceh. At-Ta'dib: Jurnal Ilmiah Prodi Pendidikan Agama Islam, 71-92.

Marzuki, M. (2011). Sejarah Dan Perubahan Pesantren Di Aceh. Millah: Jurnal Studi Agama, 11(1), 221-233.

Mashuri, M. (2013). Dinamika Sistem Pendidikan Islam Di Dayah. Jurnal Ilmiah Didaktika: Media Ilmiah Pendidikan dan Pengajaran, 13(2).

Mukti, Abd. (2017). Konstruksi Pendidikan Islam "Belajar dari Kejayaan Madrasah Zizhamiyah Dinasti Saljuq", Medan: Perdana Publishing.

Mukri, S. G. (2013). Modernisasi Sistem Pendidikan Pesantren. Fikrah, 6(1).

Qodir, A. (2013). Manajemen Sumber Daya Manusia Di Pondok Pesantren Alfalah Bakalan Kecamatan KalinyamatanKabupatenjepara. Jurnal Manajemen Pendidikan, 1(3).

Setiawan, E. (2013). Modernisasi pola sistem pendidikan pesantren (studi kasus pondok pesantren modern daarul fikri Mulyoagung dau Malang). ULUL ALBAB Jurnal Studi Islam, 14(2), 176-193.

Silahuddin, S. (2015). Transformasi Budaya Pendidikan Dayah di Aceh. Jurnal MUDARRISUNA: Media Kajian Pendidikan Agama Islam, 5(2), 377-416.

Silahuddin, S. (2016). Budaya Akademik dalam Sistem Pendidikan Dayah Salafiyah di Aceh. MIQOT: Jurnal Ilmu-ilmu Keislaman, 40(2).

Solichin, M. M. (2013). Modernisasi Pendidikan Pesantren. Jurnal Tadris Stain Pamekasan, 6(1), 28-46.

Solichin, M. (2015). Perkembangan Pendidikan Meunasah dan Dayah di Aceh. Dirāsāt: Jurnal Manajemen dan Pendidikan Islam, 1(1), 124-151.

Thahiry, Muslim, dkk. (2007). Wacana Pemikiran Santri Dayah Aceh, Banda Aceh: Kerjasama BRR Nad-Nias, PKPM Aceh dan Wacana Press.

Yacob, Ismail. (2010). Apresiasi Terhadap Kurikulum Metode dan Materi Pendidikan yang Dilaksanakan di Dayah, Banda Aceh: Pengurus Besar Persatuan Dayah Inshafuddin.

\section{Interview}

Bajaruddin, B. (2019). The results of the interview in Takengon as Treasurer of the Dayah Terpadu Al-Azhar on Thursday 4 July 2019 at 10.15 WIB.

Basari, K. (2919). The interview in Takengon as the leader of the Dayah Terpadu Al-Azhar, on Thursday 26 April 2019, at 09.27 PM. 